EGU21-1448

https://doi.org/10.5194/egusphere-egu21-1448

EGU General Assembly 2021

(C) Author(s) 2021. This work is distributed under

the Creative Commons Attribution 4.0 License.

\title{
The 2020 Activity of Kamchatkan Volcanoes and Danger to Aviation
}

\author{
Olga Girina ${ }^{1}$, Melnikov Dmitry ${ }^{1}$, Manevich Alexander ${ }^{1}$, Nuzhdaev Anton ${ }^{1}$, Romanova Iraida \\ Loupian Evgenii ${ }^{2}$, and Sorokin Aleksei ${ }^{3}$ \\ ${ }^{1}$ Institute of Volcanology and Seismology FEB RAS, Petropavlovsk-Kamchatsky, Russian Federation (girina@kscnet.ru) \\ ${ }^{2}$ Space Research Institute RAS, Moscow, Russian Federation \\ ${ }^{3}$ Computing Center FEB RAS, Khabarovsk, Russian Federation
}

Strong explosive eruptions of volcanoes are the most dangerous for aircraft because they can produce in a few hours or days to the atmosphere and the stratosphere till several cubic kilometers of volcanic ash and aerosols. Ash plumes and the clouds, depending on the power of the eruption, the strength and wind speed, can travel thousands of kilometers from the volcano for several days, remaining hazardous to aircraft, as the melting temperature of small particles of ash below the operating temperature of jet engines.

There are 30 active volcanoes in the Kamchatka, and several of them are continuously active. Scientists of KVERT monitor Kamchatkan volcanoes since 1993. In 2020, four of these volcanoes (Sheveluch, Klyuchevskoy, Bezymianny, and Karymsky) had strong and moderate explosive eruptions.

The eruptive activity of Sheveluch volcano began since 1980 (growth of the lava dome) and it is continuing at present. In 2020, strong explosions sent ash up to 7-10 km a.s.l. on 08 April, and 22 and 29 December. Ash from explosions rose up to 5-6 km a.s.l. on 13 June, and 24 December. Ash plumes extended more $625 \mathrm{~km}$ mainly to the south-east of the volcano. A form of resuspended ash was observed on 20 April, 28 June, 24 August, and 07-10 October: ash plumes extended for $310 \mathrm{~km}$ to the northeast and southeast of the volcano. Activity of Sheveluch was dangerous to international and local aviation.

Two moderate explosive-effusive eruptions of Klyuchevskoy volcano occurred in 2020: first from 01 November 2019 till 03 July 2020, and second from 30 September, it is continuing in 2021. Explosions sent ash up to $7 \mathrm{~km}$ a.s.l., gas-steam plumes containing some amount of ash extended for $465 \mathrm{~km}$ to the different directions of the volcano. The lava flows moved along Apakhonchichsky and Kozyrevsky chutes. Activity of the volcano was dangerous to local aviation.

The strong explosive eruption of Bezymianny volcano occurred on 21 October: explosions sent ash up to $11 \mathrm{~km}$ a.s.l., the large ash cloud was located over Klyuchevskoy group of volcanoes long time and later drifted up to $1200 \mathrm{~km}$ to the southeast of the volcano. Activity of the volcano was dangerous to international and local aviation.

Eruptive activity of Karymsky volcano was uneven in 2020: ash explosions were observed from one 
(June) to seven (October) days a month, for five months the volcano was quiet. Explosions rose ash up to $8 \mathrm{~km}$ a.s.l. (08 November), ash plumes and clouds drifted for $380 \mathrm{~km}$ to the different directions of the volcano. The eruptive volcanic activity was observed in April, May, June, July, October, November, and December. Activity of Karymsky was dangerous to international and local aviation. 